Article

\title{
Sechium edule (Jacq.) Swartz, a New Cultivar with Antiproliferative Potential in a Human Cervical Cancer HeLa Cell Line
}

\author{
Sandra Salazar-Aguilar ${ }^{1,2}$, Lucero del Mar Ruiz-Posadas ${ }^{1,2, *}$, Jorge Cadena-Iñiguez ${ }^{2,3}$, \\ Marcos Soto-Hernández ${ }^{1,2}$ (D), Edelmiro Santiago-Osorio ${ }^{2,4}$, Itzen Aguiñiga-Sánchez ${ }^{2,4}$, \\ Ana Rocío Rivera-Martínez ${ }^{2,4}$ and Juan Francisco Aguirre-Medina ${ }^{2,5}$ \\ 1 Postgraduate College, Campus Montecillo, Km 36.5 Mexico-Texcoco Highway, C.P. 56230 Texcoco, \\ Mexico; saguilars@colpos.mx (S.S.-A.); msoto@colpos.mx (M.S.-H.) \\ 2 Interdisciplinary Research Group of Sechium edule in Mexico (GISeM), Texcoco, Agustín Melgar 10 Street, \\ C.P. 56153 Texcoco, Mexico; jocadena@colpos.mx (J.C.-I.); edelmiro@unam.mx (E.S.-O.); \\ liberitzen@yahoo.com.mx (I.A.-S.); anarocio.rivera@hotmail.com (A.R.R.-M.); \\ juanf56@prodigy.net.mx (J.F.A.-M.) \\ 3 Postgraduate College, Campus San Luis Potosí, Iturbide No. 73 Street, Salinas de Hidalgo, \\ C.P. 78600 San Luis Potosí, Mexico \\ 4 FES Zaragoza, National Autonomous University of Mexico, Batalla 5 de mayo esq. Fuerte de Loreto, \\ Col. Ejército de Oriente, C.P. 09230 Mexico City, Mexico \\ 5 School of Higher Education of Agricultural Science, Autonomous University of Chiapas, \\ Junction Costera Higway and Pueblo de Huehuetán, Huehuetán, C.P. 30660 Chiapas, Mexico \\ * Correspondence: lucpo@colpos.mx; Tel.: +52-(595)-9520-200 (ext. 1300)
}

Received: 19 May 2017; Accepted: 14 July 2017; Published: 25 July 2017

\begin{abstract}
The Sechium edule Perla Negra cultivar is a recently-obtained biological material whose progenitors are S. edule var. nigrum minor and S. edule var. amarus silvestrys, the latter of which has been reported to have antiproliferative activity against the HeLa P-388 and L-929 cancer cell lines. The present study aimed to determine if the methanolic extract of the fruit of the Perla Negra cultivar had the same biological activity. The methanolic extract was phytochemically characterized by thin layer chromatography (TLC) and column chromatography (CC), identifying the terpenes and flavonoids. The compounds identified via high performance liquid chromatography (HPLC) were Cucurbitacins B, D, E, and I for the terpene fractions, and Rutin, Phlorizidin, Myricetin, Quercetin, Naringenin, Phloretin, Apigenin, and Galangin for the flavonoid fractions). Biological activity was evaluated with different concentrations of the methanolic extract in the HeLa cell line and normal lymphocytes. The methanolic extract inhibited the proliferation of HeLa cells ( $\mathrm{IC}_{50} 1.85 \mu \mathrm{g} \cdot \mathrm{mL}^{-1}$ ), but the lymphocytes were affected by the extract $\left(\mathrm{IC}_{50} 30.04 \mu \mathrm{g} \cdot \mathrm{mL}^{-1}\right)$. Some fractions, and the pool of all of them, showed inhibition higher than $80 \%$ at a concentration of $2.11 \mu \mathrm{g} \cdot \mathrm{mL}^{-1}$. Therefore, the biological effect shown by the methanolic extract of the Perla Negra has some specificity in inhibiting tumor cells and not normal cells; an unusual feature among molecules investigated as potential biomedical agents.
\end{abstract}

Keywords: cancer; Perla Negra; chayote; biological activity

\section{Introduction}

Chayote (Sechium edule (Jacq.) Swartz) (Cucurbitaceae) is cultivated on the American continent from Mexico to South America and the Antilles [1]. In Mexico, the states of Chiapas, Oaxaca, and Veracruz present the greatest genetic diversity worldwide; in particular, Veracruz is the state with the richest biodiversity of this species [2,3]. A wide variety of shapes, colours, flavours, and textures can be observed in the fruit. 
The importance of the cultivated S. edule biological varieties include dietary and socioeconomic aspects from the generation of profits in export markets [4]. In the pharmacological area, different studies have reported the use of parts of the plant to treat different illnesses, such as low blood pressure, and it is also used as a vasodilator [5,6]. The roots, stems, and leaves are used as antimicrobial agents [7], and the leaves with seeds are used as antioxidants [8]. On the other hand, anti-inflammatory and cardiotonic activity of the fruit has been reported $[9,10]$. Its use in the treatment of arteriosclerosis has also been reported [11], as well as in depressing the central nervous system and treating epilepsy [12].

These studies show promising uses of S. edule; however, the biological variant was not specified in any of them. This situation is important if the broad morphological and biochemical diversity contained in the intra-specific variation of the species is considered $[13,14]$, because the type and content of their secondary metabolites is very different in a variety of groups, which has repercussions on the biological activities that they may present [14].

The cytotoxicity of eight variants of the fruit from Sechium edule on different cancer cell lines has been reported [15], highlighting that varietal groups (albus dulcis, albus levis, amarus silvestrys, nigrum spinosum, and nigrum xalapensis) inhibit P-388 (mouse monocytic leukaemia) and L-929 (mouse fibrosarcoma lung) cells [16], while nigrum spinosum showed an antiproliferative effect against HeLa (human cervical cancer cell line) and L-929 [17] cells, while inhibiting the viability of WEHI-3 (mouse myelomonocytic leukaemic cell line) cells [18]. Additionally, albus levis, albus dulcis, albus minor, amarus silvestrys, nigrum spinosum, nigrum levis, nigrum xalapensis and virens levis had antiproliferative effects on L-929, HeLa, and P-388 cells [16]. The main secondary metabolites identified and related to biological activity were alkaloids, sterols, saponins, triterpenes $[9,15,19]$, saturated fatty acids esters [17], glycosylated flavonoids [19,20], and tannins [18].

From this perspective, it is relevant to perform in parallel bioprospection studies of genetic improvement programmes in Sechium edule, so that the range of outstanding genotypes for pharmacological applications that are easy and safe to use at lower concentrations can be broadened, given the plasticity of the environmental adaptation of the species [13,21,22].

The Sechium edule Perla Negra cultivar is a new genotype obtained by interspecific crossing in the field, and its progenitors are S. edule var. nigrum minor and S. edule var. amarus silvestrys. The aim of this paper was to determine the metabolite content of the methanolic extract of the fruit of this cultivar, and the potential antiproliferative effect on HeLa cells, starting from the premise that different genetic lineages can have different effects and be used as a source for complementary medicine.

\section{Materials and Methods}

Plant material: Fruits of the Perla Negra cultivar, whose genetic lineage comes from a process of improvement [23-25] of biological variants of the varietal group Sechium edule var. nigrum minor, were crossed with the group Sechium edule var. amarus silvestrys. Once the cultivar was stabilized, the fruits were collected by the Interdisciplinary Research Group of Sechium edule in Mexico, A. C. (GISeM) in the Bank of Germoplasm (19 $08^{\prime} 48^{\prime \prime}$ N, $\left.97^{\circ} 57^{\prime} 00^{\prime \prime} \mathrm{E}\right)$. A voucher specimen $631-12$ remains in the same place.

Extraction procedure: Fruits of the Perla Negra cultivar were cut into small pieces, dried at $45{ }^{\circ} \mathrm{C}$ to $10 \%$ moisture and ground to a standardized particle size of $2 \mathrm{~mm}$ [15]. Next, $1013 \mathrm{~g}$ of plant material was extracted in a batch with methanol (99.8\%, ACS, Merck, Darmstadt, Germany) for $48 \mathrm{~h}$ at room temperature $\left(20 \pm 2{ }^{\circ} \mathrm{C}\right)$, and the resultant alcoholic extract was filtered with paper 12 times, renewing the solvent until the macerated product was not coloured. Then, the solvent was evaporated at $50{ }^{\circ} \mathrm{C}$ under reduced pressure (Buchi Rotavapor R-114, Flawil Switzerland), until a crude extract, without organic solvent, was obtained [26-28]. A stock solution was made with $71.2 \mathrm{mg}$ of crude extract solubilized with $300 \mu \mathrm{L}$ of ethanol (96\%) and $700 \mu \mathrm{L}$ of phosphate buffered saline (PBS; Sigma, St. Louis, MO, USA), and corresponding dilutions were made. The obtained fractions were evaluated at $2.11 \mu \mathrm{g} \cdot \mathrm{mL}^{-1}\left(\mathrm{IC}_{50}\right.$ statistical), a stock solution was made with $5 \mathrm{mg}$ of each fraction and solubilized with $100 \mu \mathrm{L}$ of ethanol (96\%) and $900 \mu \mathrm{L}$ of PBS, and then $40 \mu \mathrm{L}$ was taken of the 
mixture and solubilized with $960 \mu \mathrm{L}$ of PBS to have the concentration defined. The pool took $2.1 \mu \mathrm{L}$ of each fraction $(42 \mu \mathrm{L})$, and $958 \mu \mathrm{L}$ of PBS. The three mixtures were centrifuged at $500 \mathrm{~g}$ for $5 \mathrm{~min}$ (Hermle-Labortechnik, Wehingen, Germany), and the supernatant was subsequently filtered and stored at $4{ }^{\circ} \mathrm{C}$.

Fractioning through Column Chromatography (CC): A sample of $10 \mathrm{~g}$ of the methanolic extract was employed, and a mobile extraction phase was applied to it with hexane at $100 \%$. Later, a hexane:ethyl acetate mixture was gradually added in a decreasing decimal relation of 90:10 until reaching its inverse, 10:90, and ending with ethyl acetate at $100 \%$. After the first stage, a second extraction was performed with ethyl acetate:methanol in the same decreasing decimal manner as the first, ending with methanol at $100 \%$ [17]; then, the sample was brought to reduced pressure at $45^{\circ} \mathrm{C}$ to make it solvent-free.

Identifying compounds by TLC: Preliminary tests were performed by thin-layer chromatography (TLC) on silica gel plates (Merck G60 70-230 mesh, Darmstadt Germany) with a mobile phase and a specific chromogenic agent. For the terpene fraction, mixtures of solvents with different polarities were used, the first with hexane:ethyl acetate (5:5), the second with hexane:ethyl acetate (2:8), and the third with ethyl acetate:methanol (8:2). They were developed with the chromogenic agent $1 \%$ vanillin and $10 \%$ sulfuric acid (in ethanol) [29], including the standards of Cucurbitacin B, D, E, and I. For the flavonoid fraction, the mobile phase of ethyl acetate:formic acid:acetic acid:water was used in the 100:11:11:26 ratio, and as the chromogenic agent, a mixture of 2-aminoethyl diphenyl-borinate:polyethylene glycol ( $1 \%$ NP, $5 \%$ PEG) was used. The standards were Rutin, Phloridzin, Myricetin, Quercetin, Naringenin, Phloretin, Apigenin, and Galangin. The plates were observed with UV at 254 and $365 \mathrm{~nm}$ (Cole-Parmer 9818, Chicago, IL, USA) before they were developed [29].

Identifying compounds with biological activity by HPLC: The compounds that had biological activity were evaluated by high performance liquid chromatography (HPLC); for the terpene fraction, the conditions were (Symmetry Shield Column RP18 $(4.6 \times 250 \mathrm{~mm}$ ), Isocratic Analysis, solvents water:methanol:acetonitrile (50:30:20); flow $1 \mathrm{~mL} \mathrm{~min}^{-1}$; pressure $179 \mathrm{bars}$; temperature $20^{\circ} \mathrm{C}$; injection volume: $20 \mu \mathrm{L} ; \lambda 1: 235 \mathrm{~nm}, \lambda 2: 254 \mathrm{~nm}$; and analysis time $50 \mathrm{~min})$. For the flavonoid fraction, the conditions were (Hypersyl ODS $\left(125 \times 40 \mathrm{~mm}\right.$ ) Hewlett Packard Column, solvents (a) $\mathrm{H}_{2} \mathrm{O}$ pH 2.5 with trifluoroacetic acid) (TFA) and (b) acetonitrile (ACN) with flow $1 \mathrm{~mL} \cdot \mathrm{min}^{-1}$, temperature $30{ }^{\circ} \mathrm{C}$, injection volume: 15-20 $\mu \mathrm{L} ; \lambda 1: 254 \mathrm{~nm}, \lambda 2: 316 \mathrm{~nm}$, and analysis time $25 \mathrm{~min})$. The standards were Rutin, Phlorizidin, Myricetin, Quercetin, Naringenin, Phloretin, Apigenin, and Galangin. Finally, the results determined the concentration of the compounds based on the injection volume and detected micrograms. The terpene fraction was taken as a reference concentration of $2 \mathrm{mg} \cdot \mathrm{mL}^{-1}$, which was $40 \mathrm{mg} \cdot \mathrm{mL}^{-1}$ for flavonoids.

Cell culture: The HeLa cervical cancer cell line was obtained from the American Type Culture Collection (ATCC) (Rockville, MD, USA). The HeLa cells and human lymphocytes obtained by peripheral blood were cultured in Petri dishes (Sarstedt AG \& Co., Wiehl, Germany) with Iscove's modified Dulbecco's medium (IMDM) (Gibco-BRL, Carlsbad, CA, USA) supplemented with 10\% foetal bovine serum (FBS) (Gibco-BRL, Carlsbad, CA, USA), 100 units $/ \mathrm{ml}$ penicillin, and $100 \mu \mathrm{g} \cdot \mathrm{mL}^{-1}$ streptomycin (Sigma-Aldrich, St. Louis, MO, USA). The cells were maintained in a humidified atmosphere with $5 \% \mathrm{CO}_{2}$ at $37^{\circ} \mathrm{C}$, and the culture medium was changed every two days.

Proliferation assay: The effect of the Sechium edule Perla Negra cultivar on cell proliferation was determined by the crystal violet assay $[30,31]$. The cells, cultured in triplicate in 96 -well plates, were HeLa cervical cancer cells $\left(2 \times 10^{4}\right.$ cell. $\left.\mathrm{mL}^{-1}\right)$ and lymphocytes human cells $\left(4 \times 10^{5} \mathrm{cell} \cdot \mathrm{mL}^{-1}\right)$; they were treated for $72 \mathrm{~h}$ with the methanolic extract at different concentrations $(1.25,1.56,1.85,2.5,5$, and $10 \mu \mathrm{g} \cdot \mathrm{mL}^{-1}$ obtained from stock solution) and the antineoplastic agent, Cisplatin ${ }^{\mathrm{TM}}\left(0.72 \mu \mathrm{g} \cdot \mathrm{mL}^{-1}\right)$. The cells were fixed with glutaraldehyde at $1 \%$ for one hour; subsequently, they were stained with crystal violet solution (Sigma, St. Louis, MO, USA) after 10\% acetic acid. The absorbance of the cells was measured at $570 \mathrm{~nm}$ using a microplate reader (Spectra Tecan Image, Grödig, Austria). 
This experiment was performed in triplicate, the statistical analysis was performed to obtain the final values, and the mean inhibition concentration $\left[\mathrm{IC}_{50}\right]$ was calculated by the linear regression equation.

Statistical Analysis: Results were taken from three independent experiments in triplicate $(n=9)$, and the data were expressed as the means \pm standard error. The statistical analysis was performed through an analysis of variance (ANOVA) and Tukey tests, with statistical significance at $p<0.001$, using Software IBM SPSS (version 20.IBM Corporation, Chicago, IL, USA).

\section{Results}

Phytochemical characterization: The metabolites identified in the plant extract of the Perla Negra cultivar were terpenes and flavonoids. The estimated yield from the plant sample of $1.13 \mathrm{~kg}$ was $7.48 \%$ after the extraction, which was equivalent to $78.302 \mathrm{~g}$ of raw methanol extract. When fractioned, it showed a composition of $27.53 \mathrm{~g}$ of terpenes distributed in 17 fractions and $32.85 \mathrm{~g}$ of flavonoids recorded in three fractions. The terpenes observed in the TLC plates were primarily related to glycosylated terpenes [32], as a function of the coloration and retention value (Rf) from dark blue, turquoise, coffee-coloured, brown, purple, dark green, to violet tones. The blue and red-violet tones were related to cucurbitacins (tetracyclic triterpenes) [29], which give a bitter flavour to the fruits [9,14]. Regarding flavonoids, a range of colours between magenta, orange, yellow, and violet was observed, which was related to the chemical groups of flavonols, flavones, and flavonones [29]. The magenta colour coincided with the standard for quercetin ( $R f 0.95$ ), the orange colour was related to the standard chlorogenic acid (Rf 0.5), and the yellow was associated with the routine standard ( $R f 0.35$ ).

Biological activity: The evaluation of the antiproliferative activity of the methanolic extract of the fruit showed that there is a dose-dependent relationship using the doses 1.25, 1.56, 1.85, 2.5, 5, and $10 \mu \mathrm{g} \cdot \mathrm{mL}^{-1}$, where the $\mathrm{IC}_{50}$ was $1.85 \mu \mathrm{g} \cdot \mathrm{mL}^{-1}$ (Figure $1 \mathrm{~B}$ ). These data are relevant when compared to the $\mathrm{IC}_{50}$ reported for Sechium edule var. amarus silvestrys of $1170 \mu \mathrm{g} \cdot \mathrm{mL}^{-1}$ (Figure 1A) [16], which is 632 times higher than the $\mathrm{IC}_{50}$ of the methanol extract. These same doses were used in an assay with normal lymphocytes, where the decrease in proliferation was not statistically significant (Figure 1B); however, it has already been reported that the normal bone marrow cells of mice are not affected by the extracts [19].

A)

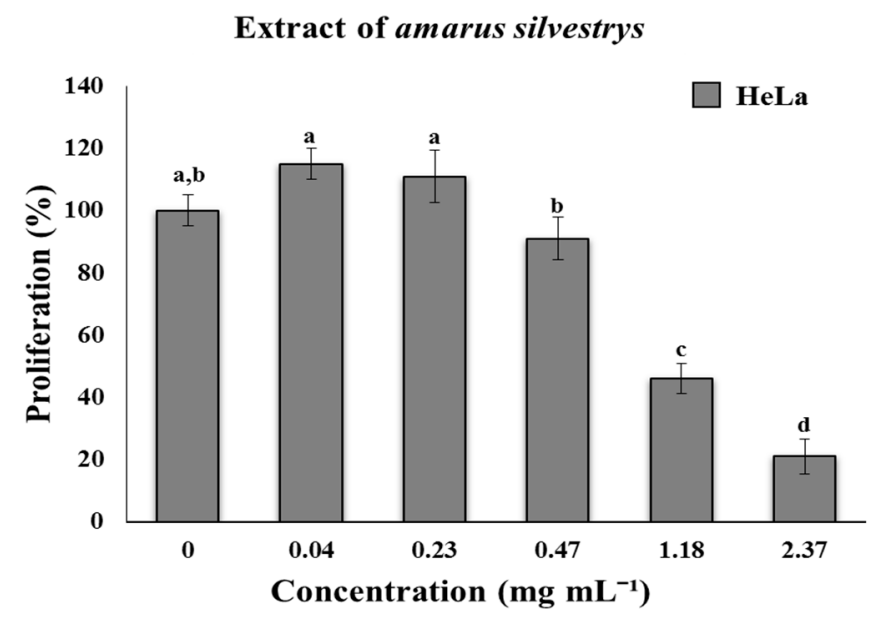

Figure 1. Cont. 
B)

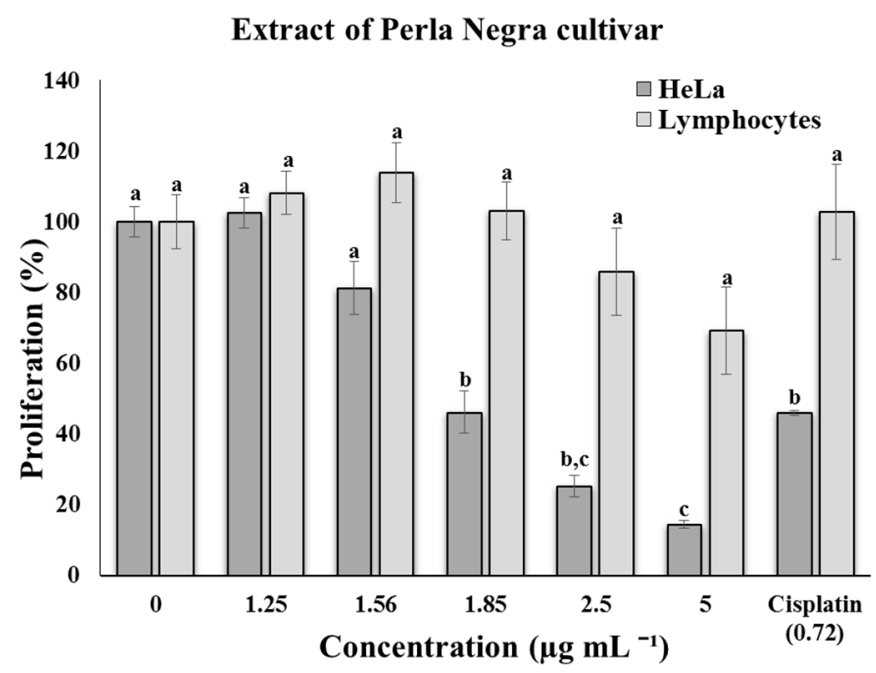

Figure 1. Proliferation assay. (A) Inhibitory effect of amarus silvestrys on HeLa cells; (B) HeLa cells and lymphocytes with the Perla Negra methanolic extract at different concentrations $\left(0 \mu \mathrm{g} \cdot \mathrm{mL}^{-1}\right.$, $1.25 \mu \mathrm{g} \cdot \mathrm{mL}^{-1}, 1.56 \mu \mathrm{g} \cdot \mathrm{mL}^{-1}, 1.85 \mu \mathrm{g} \cdot \mathrm{mL}^{-1}, 2.5 \mu \mathrm{g} \cdot \mathrm{mL}^{-1}$, and $\left.5 \mu \mathrm{g} \cdot \mathrm{mL}^{-1}\right)$ and Cisplatin $\left(0.72 \mu \mathrm{g} \cdot \mathrm{mL}^{-1}\right)$ for $72 \mathrm{~h}$. Different letters indicate statistical significances 1A (a, b, c, and d) 1B (a, b, and c) ( $p \leq 0.001)$.

Twenty fractions were obtained: 17 fractions had terpenic compounds, and 3 fractions had phenolic compounds. For the fractions, the evaluated $\mathrm{IC}_{50}$ concentration was $2.11 \mu \mathrm{g} \cdot \mathrm{mL}^{-1}$ for each fraction. From the fraction of terpenes, F15 and F7 resulted in $64 \%$ and $76 \%$ cell proliferation inhibition, respectively, F8-F11, F13, and F16 resulted in 87, 84, 86, 88, 86, and 86\% cell proliferation inhibition, respectively, and F12 resulted in 90\% cell proliferation inhibition. The F18 fraction, which was related to the flavonoids, showed $82 \%$ inhibition (Figure 2). The hexane:ethyl acetate solvent mixture was notable for the chemical fractioning of the extract with the greatest antiproliferative activity, which was attributed to its medium polarity and higher affinity with terpenes.

Additionally, it was observed that when mixing all of the fractions (pool), the antiproliferative percentage of $89 \%( \pm 0.19)$ was higher than that for many individual fractions, particularly those from hexane:ethyl acetate (50:50), others fractioned with ethyl acetate:methanol (80:20), and two fractions with flavonoids. The fractioning of the extract with mixtures both of low and high polarity (hexane:ethyl acetate 50:50, ethyl acetate:methanol 20:80) does not reflect the presence of bioactive compounds, such as terpenes, that affect the antiproliferative biological activity. In addition, the value of cell inhibition for the positive control based on Cisplatin ${ }^{\mathrm{TM}}$ was lower than ten fractions of the extract.

Identification of compounds: The identification of compounds with biological activity via TLC showed, based on the value of retention (Rf), that F7, F8, and F9 contained Cucurbitacin B (Rf 0.85) and Cucurbitacin E (Rf 0.86); F10, F11, and F12 contained Cucurbitacins D (Rf 0.76), E, and I (Rf 0.82); and F13 had Cucurbitacin E. For F15 and F16, the cucurbitacin content was not observed with this method. However, the chromatograms obtained via HPLC confirmed the results from TLC, and provided more information about the composition of all of the fractions with biological activity (Figure 3), which additionally detected other compounds different from the standard. These compounds were detected at high concentrations, but their identification was not possible, which suggests that they are cucurbitacins for which the standard was not found or that they are some other terpene with a very similar chemical skeleton to cucurbitacins.

Nine of these fractions had high terpene content obtained via CC from $10 \mathrm{~g}$ of crude extract. With respect to the yield of cucurbitacins that could be identified, Cucurbitacin D had the highest concentration, followed by B, E, and I, respectively (Table 1). 


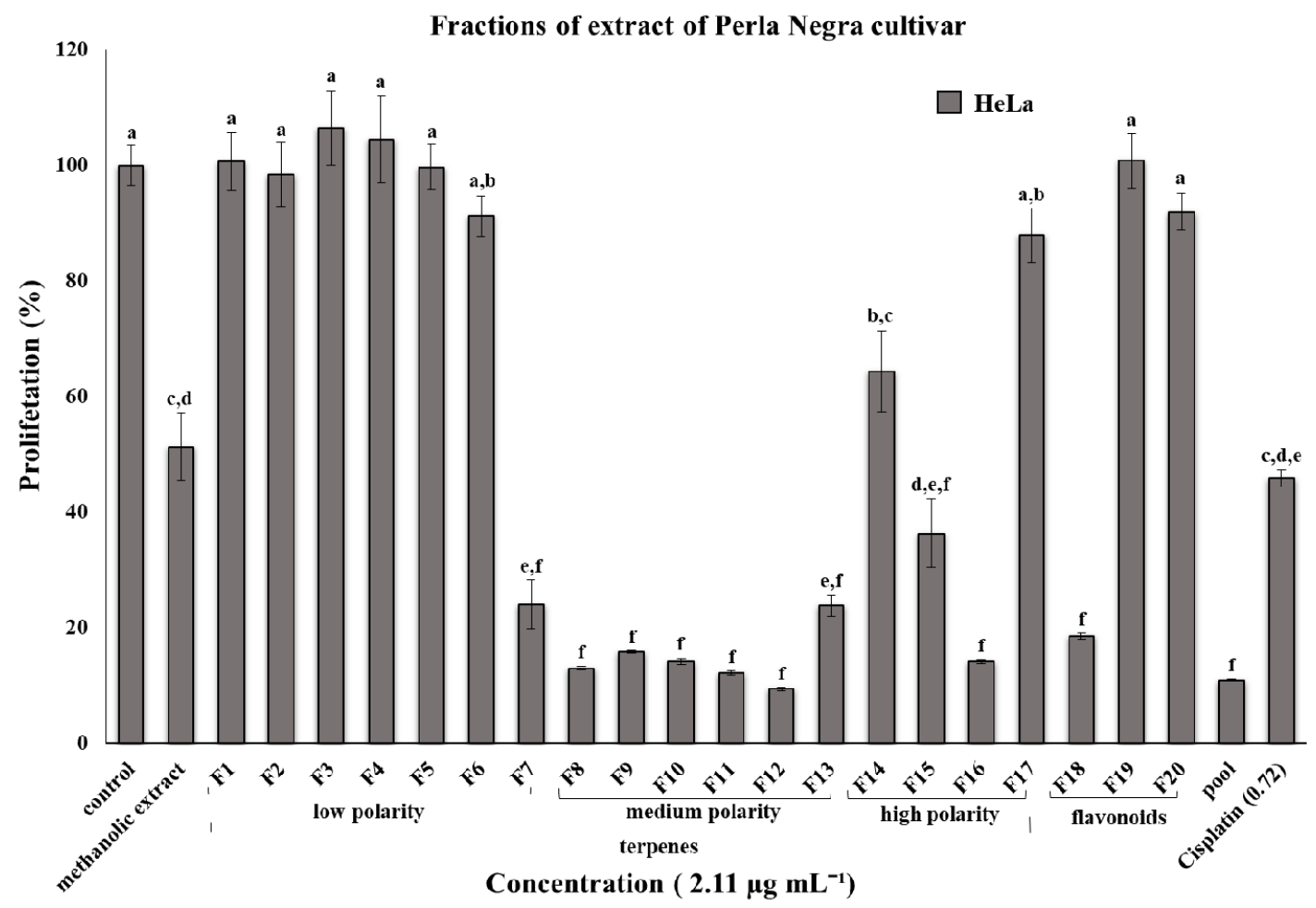

Figure 2. Proliferation assay. The effect of the Perla Negra cultivar fractions on the HeLa cell line. The polarity of fractions is related to the mobile phase of the TLC in the tracking of the terpene compounds. The cells were incubated with all fractions, the methanolic extract, and the pool at the same concentration $\left(2.11 \mu \mathrm{g} \cdot \mathrm{mL}^{-1}\right)$ and Cisplatin $\left(0.72 \mu \mathrm{g} \cdot \mathrm{mL}^{-1}\right)$ for $72 \mathrm{~h}$. Different letters indicate statistical significances $(a, b, c, d, e$, and f) $(p \leq 0.001)$.

The identification of compounds with biological activity from the flavonoid fraction, via HPLC, agreed with the TLC results. Rutin and Quercetin were identified, as well as six more flavonoids, namely, Phlorizidin, Myrecetin, Naringenin, Phloretin, Apigenin and Galangin. Apigenin is a compound that has been previously reported in Sechium edule fruits [20]. There are also peaks of compounds that could not be identified (Figure 4A,B).

Table 1. Cucurbitacin yield $\left(\mu \mathrm{g} \cdot \mathrm{mg}^{-1}\right)$ of nine fractions of the methanolic extract from the fruits of the Sechium edule Perla Negra cultivar that had biological activity against the HeLa cancer cell line.

\begin{tabular}{cccccc}
\hline FRACTION $(\mathbf{m g})$ & YIELD $(\%)$ & Cu B $(\mu \mathrm{g})$ & $\mathbf{C u} \mathbf{D}(\boldsymbol{\mu g})$ & $\mathbf{C u}$ E $(\boldsymbol{\mu g})$ & $\mathbf{C u} \mathbf{I}(\boldsymbol{\mu g})$ \\
\hline F7 & 1.59 & 29.61 & 0 & 42.39 & 0 \\
F8 & 1.44 & 48.16 & 0 & 53.84 & 0 \\
F9 & 0.74 & 53.12 & 0 & 0 & 0 \\
F10 & 1.34 & 5.52 & 75.09 & 0 & 0 \\
F11 & 1.81 & 0 & 108.60 & 1.53 & 30.40 \\
F12 & 1.49 & 0 & 134.67 & 0.46 & 8.92 \\
F13 & 1.44 & 0.29 & 7.06 & 0 & 0 \\
F15 & 1.28 & 0 & 16.13 & 0 & 1.05 \\
F16 & 3.94 & 0.30 & 594.39 & 0 & 0 \\
TOTAL & 15.07 & 137.00 & 935.94 & 98.21 & 40.37 \\
\hline
\end{tabular}

Cu B: Cucurbitacin B; Cu D: Cucurbitacin D; Cu E: Cucurbitacin E; Cu I: Cucurbitacin I. 

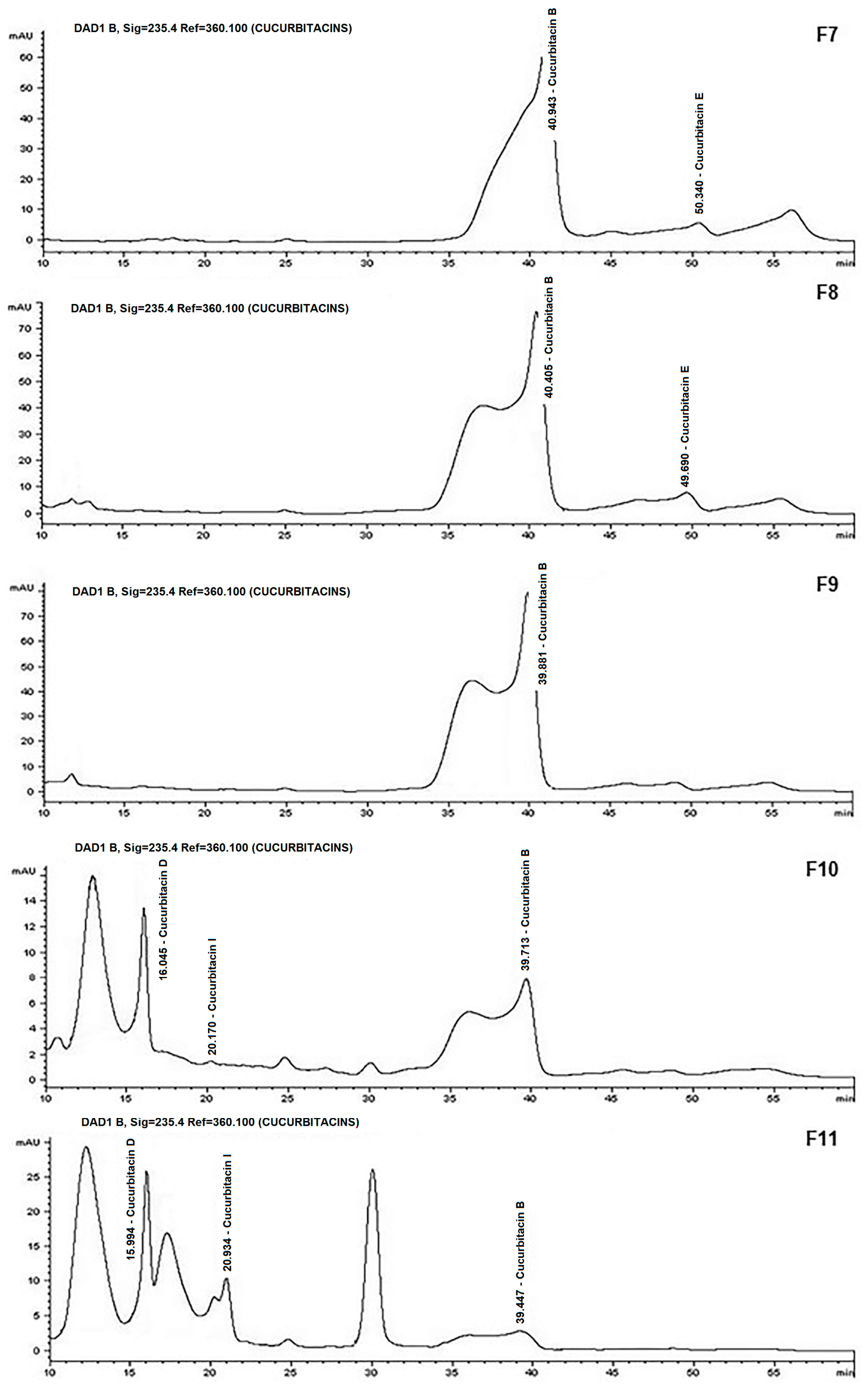

Figure 3. Cont. 
DAD1 B. Sig $=235.4$ Ref $=360.100$ (CUCURBITACINS)

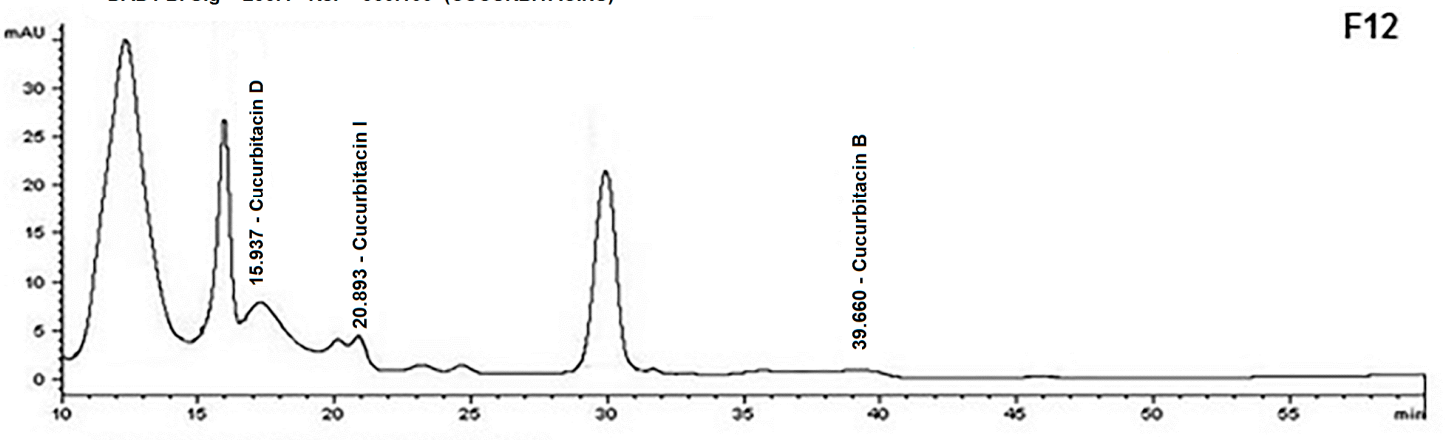

DAD1 B. Sig $=235.4$ Ref $=360.100$ (CUCURBITACINS)

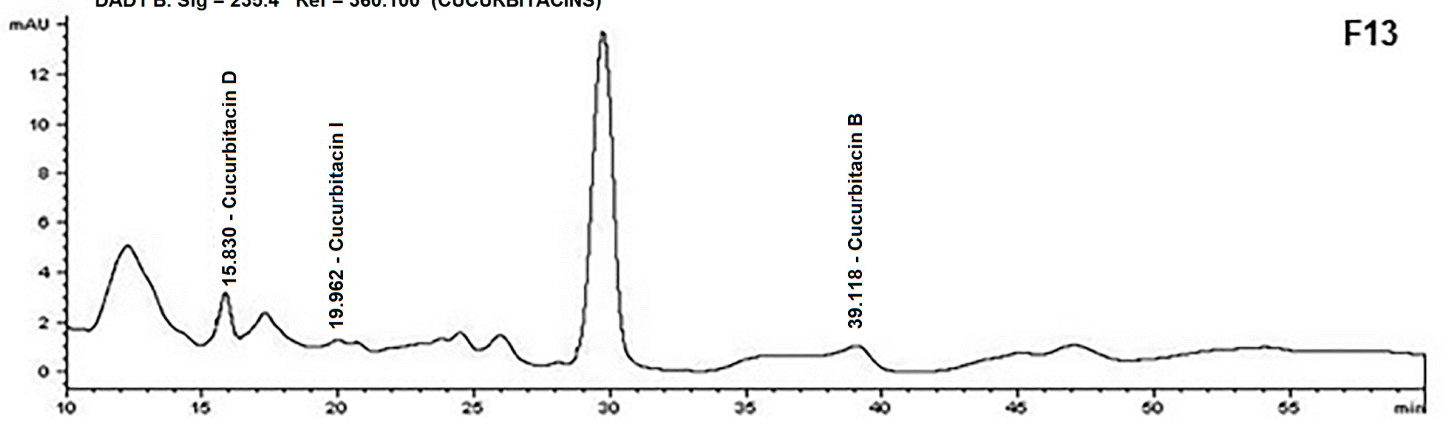

DAD1 B. Sig $=235.4$ Ref $=360.100$ (CUCURBITACINS)

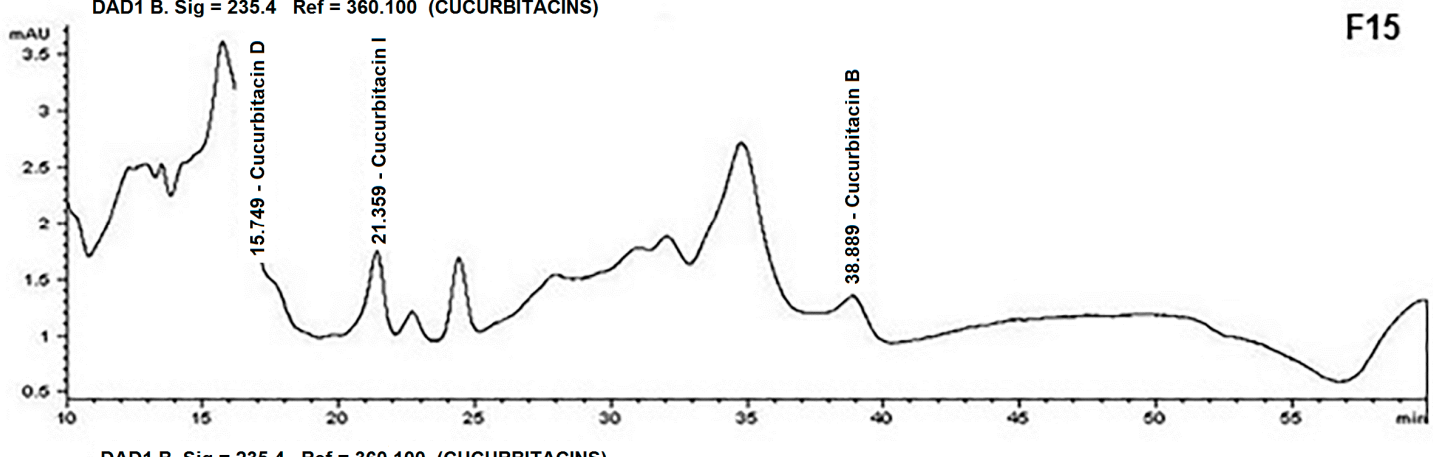

DAD1 B. Sig $=235.4$ Ref $=360.100$ (CUCURBITACINS)

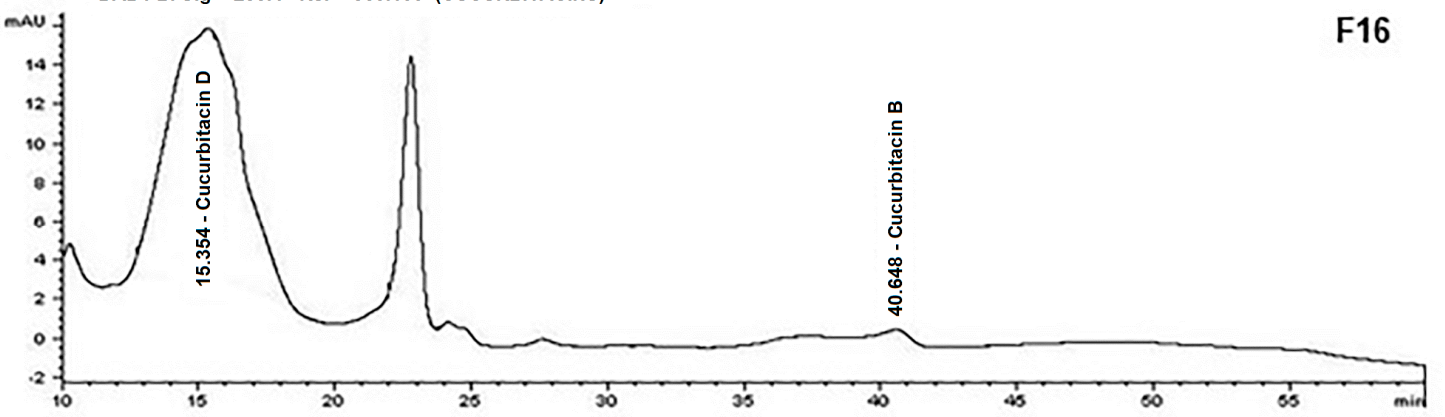

Figure 3. Identifying compounds by HPLC. Chromatograms of the terpenes (cucurbitacins) that showed biological activity, which were obtained from the methanol extract of Perla Negra through column chromatography, where the presence of cucurbitacins and other non-identified compounds is confirmed at $235 \mathrm{~nm}$. 

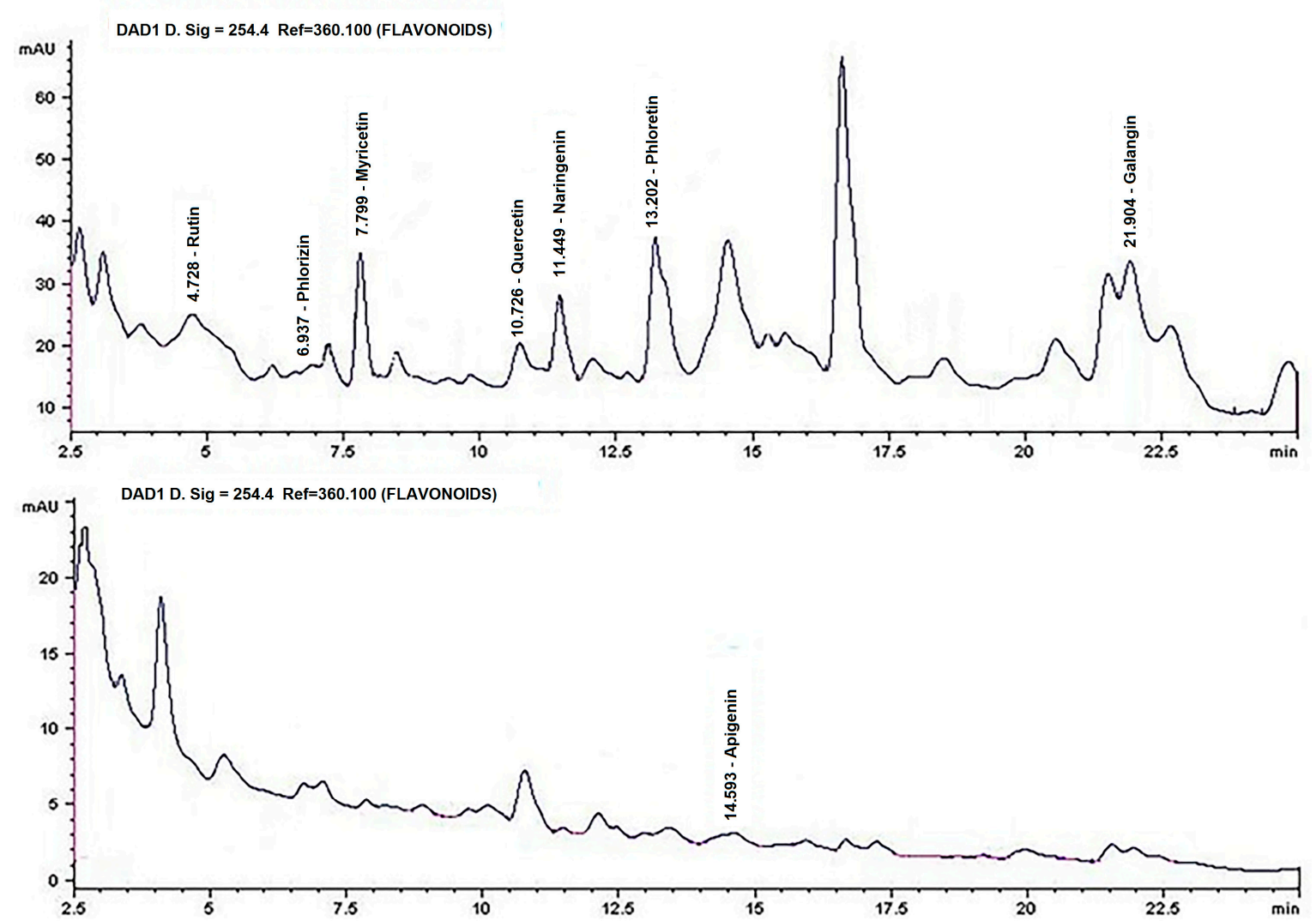

Figure 4. Identifying compounds by HPLC. (A) Chromatograms of the flavonoid fractions that showed biological activity, obtained from the methanolic extract of Perla Negra through column chromatography at $254 \mathrm{~nm}$; and (B) the presence of Apigenin at $316 \mathrm{~nm}$ and unidentified compounds.

One of the three fractions stands out because of its flavonoid content. The yield is shown in Table 2, where the Phloretin flavonoid has the highest concentration and Apigenin has lowest concentration. Of note, although Phlorizidin was identified, its concentration could not be calculated, because there were only traces of this compound.

Table 2. Flavonoid yield $\left(\mu \mathrm{g} \cdot \mathrm{mg}^{-1}\right)$ found in F18 obtained from the methanolic extract of the fruits of Sechium edule Perla Negra cultivar that had biological activity against the HeLa cancer cell line.

\begin{tabular}{ccccccccc}
\hline $\begin{array}{c}\text { Fraction } \\
(\mathbf{m g})\end{array}$ & $\begin{array}{c}\text { Yield } \\
(\mathbf{\%})\end{array}$ & $\begin{array}{c}\text { Rutin } \\
(\mu \mathrm{g})\end{array}$ & $\begin{array}{c}\text { Miricetin } \\
(\mu \mathrm{g})\end{array}$ & $\begin{array}{c}\text { Quercetin } \\
(\mu \mathrm{g})\end{array}$ & $\begin{array}{c}\text { Naringenin } \\
(\mu \mathrm{g})\end{array}$ & $\begin{array}{c}\text { Phloretin } \\
(\mu \mathrm{g})\end{array}$ & $\begin{array}{c}\text { Galangin } \\
(\mu \mathrm{g})\end{array}$ & $\begin{array}{c}\text { Apigenin } \\
(\mu \mathrm{g})\end{array}$ \\
\hline $\mathrm{F} 18$ & 12.07 & 0.34 & 1.85 & 0.25 & 2.26 & 4.72 & 0.43 & 0.18 \\
\hline
\end{tabular}

\section{Discussion}

The extracts of fruits from different varietal groups of Sechium edule have been reported with terpenes and flavonoids [14,19]; however, the type of metabolite present and its concentration depend on the varietal group, providing different qualities for its various uses and applications [14].

The alcohol extracts of different varietal groups of Sechium edule, such as nigrum spinosum, virens levis, amarus silvestrys, nigrum xalapensis, albus levis, nigrum levis, albus minor, and albus dulcis, have been reported for their antiproliferative activity against HeLa cells, with $\mathrm{IC}_{50}$ values of 930, 500, $1170,840,500,880,630$, and $1510 \mu \mathrm{g} \cdot \mathrm{mL}^{-1}$, respectively [16].

In this study, the methanolic extract of fruits of the Sechium edule Perla Negra cultivar had a greater inhibition effect on the HeLa cancer cell line, with an $\mathrm{IC}_{50}$ value of $1.85 \mu \mathrm{g} \cdot \mathrm{mL}^{-1}$, which 
is lower than that of its progenitor amarus silvestrys $\left(1170 \mu \mathrm{g} \cdot \mathrm{mL}^{-1}\right)$. This effect is due to the concentration of metabolites they contain, although only the content of cucurbitacins for amarus silvestrys ( 0.1456 g. $100 \mathrm{~g} \mathrm{~g}^{-1}$ ) has been reported [15]; Perla Negra cultivar contains $3.2568 \mathrm{~g} .100 \mathrm{~g}^{-1}$ of curcurbitacins and $1.5 \mathrm{~g} .100 \mathrm{~g}^{-1}$ of flavonoids, which provides the biological activity evaluated. This'production of metabolites is performed with epigenetic changes that are presented at the time of the interspecific cross for the creation of the Perla Negra cultivar. Interestingly, the methanolic extract of the Perla Negra cultivar does not affect the proliferation of normal human lymphocytes in the same concentration range as the HeLa cells, because the $\mathrm{IC}_{50}$ obtained for the lymphocytes is $30.04 \mu \mathrm{g} \cdot \mathrm{mL}^{-1}$. These data suggest that the extract may be selective with the cell type against which it exerts its biological activity, as it has been shown that there are extracts derived from the genus of plants that can affect leukemic lines without inducing cell death to those of the normal bone marrow [19].

Cisplatin $^{\mathrm{TM}}$ is a drug widely used against cancer in the clinic, particularly with cervix cancer. Nevertheless, the concentration of Cisplatin ${ }^{\mathrm{TM}}$ did not affect the lymphocytes because the concentration used in this study was too low to exert a cytotoxic effect on these cells, and it has been reported that Cisplatin $^{\mathrm{TM}}$ at high concentrations does not affect lymphocyte viability [33]. However, Cisplatin ${ }^{\mathrm{TM}}$ has been reported as affecting the proliferation of HeLa cells. In this study, we compared Cisplatin ${ }^{\mathrm{TM}}$ with the methanolic extract of the Perla Negra cultivar, suggesting that the content of metabolites that make up the extract may act as a cytotoxic agent for cancer cells as does the antineoplastic. It has been reported that the extract from a similar plant induces death by apoptosis to leukemic cells [19], so that this type of death could be present in the HeLa cells. It would be interesting to evaluate Cisplatin ${ }^{\mathrm{TM}}$ and the extract synergistically and see if the effect could be potentiated.

The fractions of the methanolic extract of the Perla Negra cultivar obtained by column chromatography showed greater inhibition activity with a concentration of $2.11 \mu \mathrm{g} \cdot \mathrm{mL}^{-1}$ (Figure 2). These effects were not observed in other varietal groups when fractionated. In the varietal group, nigrum spinosum, it was observed that the antiproliferative activity decreased significantly when the extract was fractioned [17]. This suggests that not all genotypes of Sechium edule have the same biological activity, and that actions taken for genetic improvement to develop cultivars like Perla Negra can improve their yield, chemical composition, and biological activity.

Different authors indicate that the occurrence of epigenetic changes during crossing and hybridization of plants $[34,35]$ generate polymorphisms with new phenotypes and new expression, which are manifested as increases in evolutionary potential [36], favouring responses to the environment, such as abiotic stress [37]. These changes can be partially stable and inheritable in plants [38].

This would explain why the Sechium edule Perla Negra cultivar expresses a different potential in terms of the synthesis of secondary metabolites with regard to its progenitors and close genotypes as well as the expression of epigenetic changes in the new cultivar, which would affect its phenotypic expression and response to the environment without directly influencing the genome. In Sechium edule, this favours the adaptive specialization to environmental changes, improving the spectrum of plasticity $[13,14]$. This species has shown a high phenotypic plasticity through its broad intraspecific variation, originating new forms, ecotypes, and varietal groups, and resulting in meta-stable phenotypical novelties attributed to epialleles that can gradually broaden biodiversity [39].

With respect to the biologically-active compounds identified in the methanolic extract of fruit from the Sechium edule Perla Negra cultivar, in the terpene fractions were Cucurbitacins D, E, B, and I (Figure 3), and Cucurbitacin D was found at a higher concentration (Table 1). Different studies report on terpenes with antiviral, antibacterial, antihypertensive, anti-hyperglycaemic and anti-parasitic activities as well as their use in central nervous system disorders and cancer treatment [40].

The biological activities of the identified cucurbitacins are as follows. For Cucurbitacin D, the following activities have been observed: antiproliferative activity in vitro in human cells from hepatic carcinoma, endometrial, and ovarian cancer [41,42]; cytotoxic activity on human cell lines from the lungs, colon, prostate, and breast cancer [43]; apoptosis induction in human cells from hepatic carcinoma [41]; and the inhibition of the cell cycle and cell growth in leukaemia [44]. 
For cucurbitacin I, the following activities have been reported: in vitro and in vivo antiproliferative effects on nasopharynx cancer [45], and cytotoxic activity on HeLa and KB cell lines [43]. Cucurbitacin $B$ has been noted to have a potent inhibitory effect on genes that act in different cell pathways that participate in cellular proliferation $[43,46]$. Cucurbitacin E affects cell division, generating in vitro disorganization, or breaking, of the cytoskeleton, and inhibiting prostate carcinoma cells [43].

It has been shown that the activity is related to the acetylation of the hydroxyl group or the presence of a double bond, which increases the lipophilicity and toxicity of different cucurbitacins [47]. Cucurbitacins B, E, and I inhibit the signalling transduction and transcription activator JACK/STAT3 [47,48], while Cucurbitacin D inhibits the cell cycle in the G2/M phase [42].

The following were identified for the flavonoid fraction: Rutin, Phlorizidin, Myricetin, Quercetin, Naringenin, Phloretin, Apigenin, and Galangin (Figure 4). Phloretin was found at the highest concentration (Table 2). These compounds have found extensive use in pharmacological areas for different conditions; they have been used as antiallergenic and antidepressant agents for treating thrombosis, diabetes mellitus, rheumatic illnesses, cardiovascular conditions, and gastric ulcers. They also have antibacterial, anti-inflammatory, antioxidant, antiviral, hepatoprotective, and anticancer activity [49-57], among other activities.

These compounds can modulate different cell processes, such as proliferation, differentiation, apoptosis, angiogenesis, and metastasis, and can thus interfere with the development of cancer. They are also efficient in eliminating oxidant molecules and various free radicals, which can be implicated in promoting tumours via DNA damage $[54,56]$.

In various in vitro studies, it was confirmed that Quercetin has inhibitory effects on different cell lines, such as colon, breast, ovary, and gastrointestinal cancer [51], as well as on lymphoma and leukaemia, cervix, stomach, ovary, and pancreas cancer cells lines, independent of polyhydroxyilation [53]. The inhibition of melanoma growth by this flavonoid and Apigenin is also reported [58]. Flavonoids like Fisetin, Apigenin, and Luteolin are inhibitors of cell proliferation [50]. With regard to the other flavonoids identified, no report was found in the reviewed literature that indicated an effect on other cell lines; therefore, this study contributes new information about flavonoids, which have antiproliferative activity against the HeLa cancer cell line with an $\mathrm{IC}_{50}$ of $2.11 \mu \mathrm{g} \cdot \mathrm{mL}^{-1}$, for the fraction from which they were identified.

The biological activity of flavonoids depends the chemical structure, degree of hydroxylation and polymerization, and other substitutions and conjugations. The major molecular mechanisms of action of flavonoids are as follows: the downregulation of the mutant p53 protein, cell cycle arrest, tyrosine kinase inhibition, inhibition of heat shock proteins, estrogen receptor binding capacity, and the inhibition of Ras protein expression [57].

Thus, the biological effect shown by the Perla Negra cultivar suggests that it could be investigated as a potential anticancer agent because its $\mathrm{IC}_{50}$ is lower than the maximum value of $20 \mu \mathrm{g} \cdot \mathrm{mL}^{-1}$ established by the United States National Cancer Institute [58], besides not affecting the proliferation of normal cells (lymphocytes). Therefore, it is essential to assess the toxicity of the extract in healthy mice to determine its safety as a potential medicinal agent. It would also be important to know the bioavailability of the extract compounds, and even their metabolism on in vivo models, before their extrapolation as an antineoplastic agent.

\section{Conclusions}

The presence of the terpene and flavonoid groups in the methanolic extract of the Perla Negra cultivar was confirmed. The Perla Negra cultivar inherited biological activity from its parents, which was likely reinforced by epigenetic changes. The methanol extract had an $\mathrm{IC}_{50}$ that was 632 times lower than that reported for its parent. The extraction and fractioning of the plant extract with medium polarity agents was more efficient, and showed higher antiproliferative activity. Ten fractions stood out with $\mathrm{IC}_{50}$ values lower than the crude extract. The compounds identified in the fractions with biological activity were Cucurbitacins D, E, B, and I for the terpene fractions and Rutin, Phlorizidin, Myricetin, 
Quercetin, Naringenin, Phloretin, Apigenin, and Galangin for the flavonoid fractions. Therefore, the antiproliferative effect shown by the Perla Negra cultivar opens the possibility of being investigated as a possible anticancer agent.

Acknowledgments: We thank the National Science and Technology Council (CONACyT, México) for the financial support for this research. We thank the GISeM and FES-Zaragoza, National Autonomous University of Mexico. Victor Cisneros and Luis Martínez, for the support provided for the research.

Author Contributions: J.C.-I. and J.F.A.-M. provided the plant material. J.C.-I. and L.R.-P. conceived of and designed the experiment. M.S.-H. and S.S.-A. performed the phytochemical characterization and compound identification. S.S.-A. and A.R.R.-M. performed the experiments. E.S.-O., L.R.-P. and I.A.-S. analysed the data. J.F.A.-M., M.S.-H. and I.A.-S. contributed the reagents, materials, analysis, and tools. S.S.-A. wrote the paper.

Conflicts of Interest: The authors declare that they have no conflicts of interest. The funding sponsors did not have any role in the design of the study; collection, analyses, or interpretation of data; writing of the manuscript; or decision to publish the results.

\section{References}

1. Flores, M.E. The chayote, Sechium edule Swartz (Cucurbitaceae). Rev. Biol. Trop. 1989, 37, 1-54. Available online: https:/ / www.ncbi.nlm.nih.gov/pubmed/2690200 (accessed on 30 March 2017). [PubMed]

2. Rzedowski, J. Aspectos de las plantas ornamentales mexicanas. Chapingo Serie Hortic. 1995, 1, 5-7.

3. Lira-Saade, R. Chayote. Sechium edule (Jacq.) Sw. In Promoting the Conservation and Use of Underutilized and Neglected Crops. 8; Institute of Plant Genetics and Crop Plant Research; Gatersleben/International Plant Genetic Resources Institute: Rome, Italy, 1996; p. 57. Available online: http:/ /pdf.usaid.gov/pdf_docs/ Pnach876.pdf (accessed on 29 March 2017).

4. Avendaño-Arrazate, C.H.; Cadena-Iñiguez, J.; Arevalo-Galarza, M.L.C.; Campos-Rojas, E.; Cisneros-Solano, V.M.; Aguirre-Medina, J.F. Las Variedades del Chayote Mexicano, Recurso Ancestral con Potencial de Comercialización; Grupo Interdisciplinario de Investigación en Sechium edule en México AC (GISeM): Estado de México, Mexico, 2010. Available online: http://snics.mx/sinarefi/biblioteca/Las\% 20variedades\%20dek\%20chayote\%20mexicano.\%20recurso\%20ancestral\%20con $\% 20$ potencial $\% 20$ de $\%$ 20comercializacion.pdf (accessed on 29 March 2017).

5. Cambar, P.J.; Portillo, P.; Tabora, F.E.; de Pineda, L.; Tovar, O.; Casco, J.; Alvarado, C.; Díaz, G.; Casco, B.; Cantillo, L. Estudio preliminar sobre las acciones farmacológicas de Sechium edule. Rev. Méd. Hondur. 1980, 48, 97-99. Available online: http://www.bvs.hn/RMH/pdf/1980/pdf/Vol48-4-1980-3.pdf (accessed on 29 March 2017).

6. Cambar, P.J. Algunos estudios farmacológicos de las plantas medicinales en Honduras. Rev. Méd. Hondur. 1985, 53, 190-196. Available online: http:/ / www.bvs.hn/RMH/pdf/1985/pdf/Vol53-3-1985-3.pdf (accessed on 29 March 2017).

7. Ordoñez, A.A.L.; Gomez, J.D.; Cudmani, N.M.; Vattuone, M.A.; Isla, M.I. Antimicrobial activity of nine extracts of Sechium edule (Jacq.) Swartz. Microb. Ecol. Health Dis. 2003, 15, 33-39. [CrossRef]

8. Ordoñez, A.A.L.; Gomez, J.D.; Vattuone, M.A.; Isla, M.I. Antioxidant activities of Sechium edule (Jacq.) Swartz extracts. Food Chem. 2006, 97, 452-458. [CrossRef]

9. Salama, A.M.; Polo, A.E.; Contreras, C.R.; Maldonado, L. Análisis fitoquímico preliminar y determinación de las actividades antiinflamatoria y cardíaca de los frutos de Sechium edule. Rev. Colomb. Cienc. Quím. Farm. 1986, 15, 79-82. Available online: http:/ / www.ciencias.unal.edu.co/unciencias/data-file/farmacia/revista/ V15P79--82.pdf (accessed on 29 March 2017).

10. Salama, A.M.; Achenbach, H.; Sánchez, M.Y.; Gutiérrez, M. Aislamiento e identificación de glicósidos antiinflamatorios de los frutos de Sechium edule. Rev. Colomb. Cienc. Quím. Farm. 1987, 16, 15-16. Available online: http:/ / www.revistas.unal.edu.co/index.php/rccquifa/article/viewFile/56592/55530 (accessed on 29 March 2017).

11. Gordon, E.A.; Guppy, L.J.; Nelson, M. The antihypertensive effects of the Jamaican Cho-Cho (Sechium edule). West Indian Med. J. 2000, 49, 27-31. Available online: https://www.ncbi.nlm.nih.gov/pubmed/10786447 (accessed on 29 March 2017). [PubMed]

12. Mohammed, F.S.; Ahmed, S.; Dey, S. Antiepileptic and central nervous system depressant activity of Sechium edule fruit extract. Bangladesh J. Pharmacol. 2012, 7, 199-202. [CrossRef] 
13. Cadena-Iñiguez, J.; Avendaño-Arrazate, C.H.; Soto-Hernández, M.; Ruiz-Posadas, L.M.; Aguirre-Medina, J.F.; Arévalo-Galarza, L. Infraspecific variation of Sechium edule in the state of Veracruz, Mexico. Genet. Resour. Crop Evol. 2008, 55, 835-847. [CrossRef]

14. Cadena-Iñiguez, J.; Soto, H.M.; Arévalo, G.M.L.; Avendaño, A.C.H.; Aguirre, M.J.F.; Ruiz, P.L.M. Caracterización bioquímica de variedades domesticadas de Sechium edule (Jacq.) Sw. comparadas con parientes silvestres. Rev. Chapingo Ser. Hortic. Ed. Espec. 2011, 17, 45-55. Available online: http:/ / www.scielo.org.mx/pdf/rcsh/v17nspe2/v17nspe2a5.pdf (accessed on 29 March 2017).

15. Cadena-Iñiguez, J.; Arévalo-Galarza, L.; Avendaño-Arrazate, C.H.; Soto-Hernández, M.; Ruiz-Posadas, L.M.; Santiago-Osorio, E.; Acosta-Ramos, M.; Cisneros-Solano, V.M.; Aguirre-Medina, J.F.; Ochoa-Martínez, D. Production, genetics, postharvest management and pharmacological characteristics of Sechium edule (Jacq.) Sw. Fresh Prod. Gl. Sci. Books 2007, 1, 41-53. Available online: http:/ /www.globalsciencebooks.info/Online/ GSBOnline/images/0706/FP_1(1)/FP_1(1)41-53o.pdf (accessed on 29 March 2017).

16. Cadena-Iñiguez, J.; Soto-Hernández, M.; Torres-Salas, A.; Aguiñiga-Sánchez, I.; Ruiz-Posadas, L.; Rivera-Martínez, A.R.; Avendaño-Arrazate, C.; Santiago-Osorio, E. The antiproliferative effect of chayote varieties (Sechium edule (Jacq.) Sw.) on tumour cell lines. J. Med. Plants Res. 2013, 7, 455-460. [CrossRef]

17. Monroy-Vázquez, M.E.; Soto-Hernández, M.; Cadena-Iñiguez, J.; Santiago-Osorio, E.; Ruiz-Posadas, L.M.; Rosas-Acevedo, H. Estudio biodirigido de un extracto alcohólico de frutos de Sechium edule (Jacq.) Swartz. Agrociencia 2009, 43, 777-790. Available online: http://www.scielo.org.mx/pdf/agro/v43n8/v43n8a2.pdf (accessed on 29 March 2107).

18. Aguiñiga-Sánchez, I. Potencial Antileucémico In Vitro de Extractos de Cuatro Genotipos de Sechium spp. (Cucurbitaceae). Tesis de Maestría, Colegio de Postgraduados: Montecillo Texcoco, Mexico, 2013; p. 109.

19. Aguiñiga-Sánchez, I.; Soto-Hernández, M.; Cadena-Iñiguez, J.; Ruíz-Posadas, L.M.; Cadena-Zamudio, J.D.; González-Ugarte, A.K.; Weiss-Steiderd, B.; Santiago-Osorio, E. Fruit extract from a Sechium edule hybrid induce apoptosis in leukaemic cell lines but not in normal cells. Nutr. Cancer. 2015, 67, 1-8. [CrossRef] [PubMed]

20. Siciliano, T.; Tommasi, N.; de Morelli, I.; Braca, A. Study of Flavonoids of Sechium edule (Jacq) Swartz (Cucurbitaceae) different edible organs by liquid chromatography photodiode array mass spectrometry. J. Agric. Food Chem. 2004, 52, 6510-6515. Available online: http://pubs.acs.org/doi/pdf/10.1021/jf040214q (accessed on 29 March 2017). [CrossRef] [PubMed]

21. Palacios-López, K.; Rodríguez-López, N. Plasticidad fenotípica en Lippia alba (Verbenaceae) en respuesta a la disponibilidad hídrica en dos ambientes lumínicos. Acta Biol. Colomb. 2007, 12, 187-198. Available online: http: / / www.redalyc.org/articulo.oa?id=319027880011 (accessed on 29 March 2017).

22. Villamizar, C.J.M.; Rodríguez, L.N.F.; Tezara, F.W. Plasticidad fenotípica en plantas de Lippia dulcis (Verbenaceae) sometidas a déficit hídrico. Acta Biol. Colomb. 2012, 17, 363-378. Available online: http:/ / www.revistas.unal.edu.co/index.php/actabiol/article/view/27841/32947 (accessed on 27 March 2017).

23. Molina, G.J.D. Selección masal para resistencia a sequía de maíz. Agrociencia 1980, 42, 69-77.

24. Avendaño Arrazate, C.H.; Molina Galán, J.D.; Moreno Pérez, E.D.C.; Cadena Iñiguez, J.; Aguirre Medina, J.F.; Rincón Enríquez, G. Respuesta a la selección para resistencia a sequía en maíz (Zea mays, L.). Interciencia 2009, 34, 801-807. Available online: http:/ / www.scielo.org.ve/scielo.php?script=sci_arttext\&pid=S037818442009001100010 (accessed on 29 March 2017).

25. Avendaño-Arrazate, C.M.; Cadena-Iñiguez, J.; Arévalo-Galarza, M.L.C.; Cisneros-Solano, V.M.; Morales-Flores, F.J.; Ruiz-Posadas, L.M. Mejoramiento genético participativo en chayote. Agroproductividad 2014, 7, 30-39. Available online: http://www.colpos.mx/wb_pdf/Agroproductividad/2014/ AGROPRODUCTIVIDAD_VI_2014.pdf (accessed on 29 March 2017).

26. Che, C.; Fang, X.; Phoebe, C.H.; Kiunghorn, A.D.; Farnswworth, N.R. High-field 1H-NRM spectral analysis of some cucurbitacins. J. Nat. Prod. 1985, 48, 429-434. [CrossRef] [PubMed]

27. Afifi, M.S.; Ross, S.A.; Sohly, M.A.; Naeem, Z.E.; Halaweish, F.T. Cucurbitacins of Cucumis prophetarum and Cucumis prophetarum. J. Chem. Ecol. 1999, 25, 847-859. [CrossRef]

28. Cadena-Iñiguez, J. Caracterización Morfoestructural, Fisiológica, Química y Genética de Diferentes Tipos de Chayote [Sechium edule (Jacq.) Sw.]. Ph.D. Thesis, Colegio de Postgraduados, Montecillo, Texcoco, Estado de México, México, 2005; p. 156.

29. Wagner, H.; Bland, S. Plant Drug Analysis: A Thin Layer Chromatography Atlas, 2nd ed.; Springer: Munuch, Germany, 2001; p. 371. 
30. Gillies, R.; Didier, N.; Dentosn, M. Determination of cell number in monolayer cultures. Anal. Biochem. 1986, 159, 109-113. [CrossRef]

31. Kueng, W.; Silver, E.; Eppnberg, V. Quantification of cell cultured on 96-wels plates. Anal. Biochem. 1989, 186, 16-19. [CrossRef]

32. Gershenzon, J.; Croteau, R. Terpenoids. In Hervibores Their Interactions with Secondary Plant Metabolites, 2nd ed.; Rosenthal, G.A.Y., Berenbaum, M.R., Eds.; Academic Press, Inc.: San Diego, CA, USA, 1991; Chapter 5; Volume 1, p. 468.

33. Blasiak, J.; Kowalik, J.; Malecka-Panas, E.; Drzewoski, J.; Wojewódzka, M. DNA Damage and repair in human lymphocytes exposed to three anticancer platinum drugs. Teratog. Carcinnog. Mutagen. 2000, 20, 119-131. Available online: http:/ / onlinelibrary.wiley.com/doi/10.1002/(SICI)1520-6866(2000)20:3\%3C119:: AID-TCM3\%3E3.0.CO;2-Z/epdf (accessed on 26 April 2017). [CrossRef]

34. Xiong, L.Z.; Xu, C.G.; Saghai Maroof, M.A.; Zhang, Q.F. Patterns of cytosine methylation in an elite rice hybrid and its parental lines by a methylation-sensitive amplification polymorphism technique. Mol. Gen. Genet. 1999, 261, 439-446. Available online: http://www.ncpgr.cn/papers/xiong_mgg.pdf (accessed on 29 March 2017). [CrossRef] [PubMed]

35. Bossdorf, O.; Richards, C.L.; Pigliucci, M. Epigenetics for ecologists. Ecol. Lett. 2007, 10, 1-10. [CrossRef] [PubMed]

36. Richards, E.J. Inherited epigenetic variation-Revisiting soft inheritance. Nat. Rev. Genet. 2006, 7, $395-401$. Available online: http:/ / www.nature.com/nrg/journal/v7/n5/pdf/nrg1834.pdf (accessed on 29 March 2017). [CrossRef] [PubMed]

37. Guangyuan, L.; Xiaoming, W.; Biyun, C.; Gao, G.; Kun, X. Evaluation of Genetic and Epigenetic Modification in Rapeseed (Brassica napus) Induced by Salt Stress. J. Integr. Plant Biol. 2007, 49, 1599-1607. [CrossRef]

38. Jirtle, R.L.; Skinner, M.K. Environmental epigenomics and disease susceptibility. Nat. Rev. Genet. 2007, 8, 253-262. [CrossRef] [PubMed]

39. Masuelli, R.W.; Marfil, C.F. Variabilidad epigenética en plantas y evolución. J. Basic Appl. Genet. 2011, 22, 1-8. Available online: http:/ / www.scielo.org.ar/pdf/bag/v22n1/v22n1a01.pdf (accessed on 29 March 2017).

40. Brahmkshatriya, P.P.; Brahmkshatriya, P.S. Terpenes: Chemistry, biological role, and therapeutic applications. In Natural Products; Ramawat, K.G., Mérillon, J.M., Eds.; Springer: Berlin, Germany, 2013; Chapter 86; pp. 2665-2691. Available online: https://link.springer.com/referenceworkentry/10.1007\%2F978-3-64222144-6_120 (accessed on 29 March 2017).

41. Takahashi, N.; Yoshida, Y.; Sugiura, T.; Matsuno, K.; Fujino, A.; Yamashita, U. Cucurbitacin D isolated from Trichosanthes kirilowii induces apoptosis in human hepatocellular carcinoma cells in vitro. Int. Immunopharmacol. 2009, 9, 508-513. [CrossRef] [PubMed]

42. Ishii, T.; Kira, N.; Yoshida, T.; Narahara, H. Cucurbitacin D induces growth inhibition, cell cycle arrest, and apoptosis in human endometrial and ovarian cancer cells. Tumor Biol. 2013, 34, 285-291. [CrossRef] [PubMed]

43. Chao-Chen, J.; Hua-Chiu, M.; Lin-Nie, R.; Cordell, A.G.; Qiu, S.X. Cucurbitacins and cucurbitane glycosides: Structures and biological activities. Nat. Prod. Rep. 2005, 22, 386-399. Available online: http:/ / pubs.rsc.org/ en/content/articlepdf/2005/np/b418841c (accessed on 29 March 2017). [CrossRef] [PubMed]

44. Ding, N.; Yamashita, U.; Matsuoka, H.; Sugiura, T.; Tsukada, J.; Noguchi, J.; Yoshida, Y. Apoptosis induction through proteasome inhibitory activity of Cucurbitacin D in human T-cell leukemia. Cancer 2011, 117, 2735-2746. [CrossRef] [PubMed]

45. Lui, V.; Yau, D.; Wong, E.; Ng, Y.-K.; Lau, C.; Ho, Y.; Chan, J.; Hong, B.; Ho, K.; Cheung, C.; et al. Cucurbitacin I elicits anoikis sensitization, inhibits cellular invasion and in vivo tumor formation ability of nasopharyngeal carcinoma cells. Carcinogenesis 2009, 30, 2085-2094. [CrossRef] [PubMed]

46. Kapoor, S. Cucurbitacin B and its rapidly emerging role in the management of systemic malignancies besides lung carcinomas. Cancer Biother. Radiopharm. 2013, 28, 359. [CrossRef] [PubMed]

47. Soto-Hernández, M.; Cadena-Iñiguez, J.; Arévalo-Galarza, L.; Santiago-Osorio, E.; Aguiñiga-Sánchez, I.; Ruíz-Posadas, L.; del Mar Ruíz-Posadas, L. Lead compounds from Cucurbitaceae for the treatment of cáncer. In Phytochemicals-Isolation, Characterization and Role in Human Health; Rao, A.V., Rao, L.G., Eds.; Intech: Rijeka, Croatia, 2015; Chapter 12; pp. 289-303. [CrossRef] 
48. Alghasham, A.A. Cucurbitacins-A promising target for cancer therapy. Int. J. Health Sci. 2013, 7, 67-79. Available online: https:/ /www.ncbi.nlm.nih.gov/pmc/articles/PMC3612419/ (accessed on 29 March 2017). [CrossRef]

49. Cartaya, O.; Reynaldo, I. Flavonoides: Características químicas y aplicaciones. Cultiv. Trop. 2001, $22,5-14$. Available online: http: / www.redalyc.org/pdf/1932/193215009001.pdf (accessed on 29 March 2017).

50. Nijveldt, R.J.; van Nood, E.; van Hoorn, D.E.C.; Boelens, P.G.; van Norren, K.; van Leeuwen, P.A.M. Flavonoids: A review of probable mechanisms of action and potential applications. Am. J. Clin. Nutr. 2001, 74, 418-425. Available online: http:/ / ajcn.nutrition.org/content/74/4/418.full.pdf+html (accessed on 29 March 2017). [PubMed]

51. Martínez-Flórez, S.; González-Gallego, J.; Culebras, J.M.; Tuñón, M.J. Los flavonoides: propiedades y acciones antioxidantes. Nutr. Hosp. 2002, 17, 271-278. Available online: https:/ / www.google.com.mx/search?q=Los+flavonoides\%3A+propiedades+y+acciones+antioxidantes+ Nutr.+Hosp\&rlz=1C1AVNE_enMX678MX687\&oq=Los+flavonoides\%3A+propiedades+y+acciones+ antioxidantes+Nutr.+Hosp\&aqs=chrome..69i57.3802j0j8\&sourceid=chrome\&ie=UTF-8 $\quad$ (accessed on 30 March 2017).

52. Álvarez, C.E.; Orallo, C.F. Actividad biológica de los flavonides (I). Acción frente al cáncer. Offarm Bioquími. 2003, 22, 130-140. Available online: http://www.elsevier.es/es-revista-offarm-4-articulo-actividadbiologica-los-flavonoides-i-13054406 (accessed on 29 March 2017).

53. Kanadaswami, C.; Lee, L.T.; Lee, P.P.H.; Hwang, J.J.; Ke, F.C.; Huang, Y.T.; Lee, M.T. The Antitumor Activities of Flavonoids. In Vivo 2005, 19, 895-910. Available online: http:/ /iv.iiarjournals.org/content/19/5/895.long (accessed on 29 March 2017).

54. Agrawal, A.D. Pharmacological activities of flavonoids: A review. Pharma. Sienc. Nanotech. 2011, 4, 1394-1398. Available online: http://www.ijpsnonline.com/Issues/1394_full.pdf (accessed on 29 March 2017).

55. Kaur, S.H.; Kumar, B.; Prasher, S.; Tiwari, P.; Salhan, M.; Sharma, P. A Review of phytochemistry and pharmacology of flavonoids. Int. Pharm. Sci. 2011, 1, 25-41. Available online: http://www.academia.edu/ 8181572/A_Review_of_Phytochemistry_and_Pharmacology_of_Flavonoids_INTRODUCTION (accessed on 29 March 2017).

56. Kumar, S.; Pandey, A.K. Chemistry and biological activities of flavonoids: An overview. Sci. World J. 2013, 2013, 162750. [CrossRef] [PubMed]

57. Caltagirone, S.; Rossi, C.; Poggi, A.; Ranelletti, F.O.; Natali, P.G.; Brunetti, M.; Aiello, F.B.; Piantelli, M. Flavonoids apigenin and quercetin inhibit melanoma growth and metastatic potential. Int. J. Cancer 2000, 87, 595-600. Available online: https://www.researchgate.net/publication/227498089_Flavonoids_ Apigenin_and_Quercetin_inhibit_melanoma_growth_and_metastatic_potential (accessed on 29 March 2017). [CrossRef]

58. Boik, J. Natural Compounds in Cancer Therapy: Promising Nontoxic Antitumor Agents form Plants and Other Natural Sources; Oregon Medical Press: Princeton, MN, USA, 2001.

(C) 2017 by the authors. Licensee MDPI, Basel, Switzerland. This article is an open access article distributed under the terms and conditions of the Creative Commons Attribution (CC BY) license (http://creativecommons.org/licenses/by/4.0/). 